\title{
Microbiological Lessons Learned From the Space Shuttle
}

\author{
Duane L. Pierson ${ }^{1}$ and C. Mark Ott ${ }^{5}$ \\ National Aeronautics and Space Administration, Houston, TX 77058 \\ Rebekah Bruce ${ }^{2}$, Victoria A. Castro ${ }^{3}$, and Satish K. Mehta ${ }^{4}$ \\ Enterprise Advisory Services, Inc., Houston, TX 77074
}

\begin{abstract}
After 30 years of being the centerpiece of NASA's human spacecraft, the Space Shuttle will retire. This highly successful program provided many valuable lessons for the International Space Station (ISS) and future spacecraft. Major microbiological risks to crewmembers include food, water, air, surfaces, payloads, animals, other crewmembers, and ground support personnel. Adverse effects of microorganisms are varied and can jeopardize crew health and safety, spacecraft systems, and mission objectives. Engineering practices and operational procedures can minimize the negative effects of microorganisms. To minimize problems associated with microorganisms, appropriate steps must begin in the design phase of new spacecraft or space habitats. Spacecraft design must include requirements to control accumulation of water including humidity, leaks, and condensate on surfaces. Materials used in habitable volumes must not contribute to microbial growth. Use of appropriate materials and the implementation of robust housekeeping that utilizes periodic cleaning and disinfection will prevent high levels of microbial growth on surfaces. Air filtration can ensure low levels of bioaerosols and particulates in the breathing air. The use of physical and chemical steps to disinfect drinking water coupled with filtration can provide safe drinking water. Thorough preflight examination of flight crews, consumables, and the environment can greatly reduce pathogens in spacecraft. The advances in knowledge of living and working onboard the Space Shuttle formed the foundation for environmental microbiology requirements and operations for the International Space Station (ISS) and future spacecraft. Research conducted during the Space Shuttle Program resulted in an improved understanding of the effects of spaceflight on human physiology, microbial properties, and specifically the host-microbe interactions. Host-microbe interactions are substantially affected by spaceflight. Astronaut immune functions were found to be altered. Selected microorganisms were found to become more virulent during spaceflight. The increased knowledge gained on the Space Shuttle resulted in further studies of the host-microbe interactions on the ISS to determine if countermeasures were necessary. Lessons learned from the Space Shuttle Program were integrated into the ISS resulting in the safest space habitat to date.
\end{abstract}

\section{Introduction}

The launch of the Space Shuttle Columbia in April 1981 began a new era of human space flight, the reusable spacecraft. The Space Shuttle provided unparalled access to space carrying up to seven multinational crewmembers into low Earth orbit for up to 16-days to study space, life, and Earth sciences. In addition, the Space Shuttle provided the heavy lift capability necessary for the Hubble Telescope and the assembly of the International Space Station (ISS). The Space Shuttle also presented many challenges to habitability engineers and microbiologists to ensure a safe environment for astronauts for repeated missions. These challenges increased in the relatively small, crowded, and closed environments for extended periods. Since the health, safety, and productivity of the crew depended upon a safe environment, a rigorous plan to control microbial contamination was developed (1). This plan addressed major microbiological risks and included preflight analyses of internal

\footnotetext{
${ }^{1}$ Laboratory Manager, Johnson Space Center Microbiology Laboratory, 2101 Nasa Parkway/SF24

${ }^{2}$ Senior Scientist, Johnson Space Center Microbiology Laboratory, 6671 Southwest Freeway/Suite 800

${ }^{3}$ Laboratory Supervisor, Johnson Space Center Microbiology Laboratory, 6671 Southwest Freeway/Suite 800

${ }^{4}$ Senior Scientist, Johnson Space Center Microbiology Laboratory, 6671 Southwest Freeway/Suite 800

${ }^{5}$ Microbiologist, Johnson Space Center Microbiology Laboratory, 2101 Nasa Parkway/SF24
} 
environment (surfaces and air) and consumables (food and water). Airborne bacteria and fungi were recognized as important contributors to indoor air quality and as potential threats to human health (2). Since the inception of the U.S. human exploration of space programs, the spacecraft environment has been microbiologically monitored to ensure safety. The Apollo spacecraft were monitored only prior to flight (3). In-flight air samples for microbial analysis were first taken on the Skylab, the U.S.'s first space station (4). Acceptability limits for bacteria and fungi in the Space Shuttle environment and for consumables were established. Air and surfaces were monitored pre- and post flight in addition to in-flight (selected flights) to characterize the $65 \mathrm{~m}^{3} \mathrm{crew}$ compartment and the Spacelab (when present). Typically, bacterial and fungal levels in the air and on the surfaces did not exceed expected levels $(5,6)$.

The Space Shuttle and the Spacelab provided the opportunity for many human and animal physiological studies along with many experiments with plants and microorganisms. Our understanding of the effects of spaceflight on these life forms was greatly enhanced during the Space Shuttle Program (SSP). Some bacteria and fungi were shown to be more virulent as a result of spaceflight (7-10). Immune studies showed decreases in innate immunity, cell mediated immunity (11-15), and increased latent virus reactivation (16-19). The approaches taken to ensure a microbiologically safe and productive environment for astronauts to work and live, along with microbiological monitoring results, various anomalies, and results of major infectious disease related research are discussed. The conclusions reached resulted in the lessons learned from over 30 years of Space Shuttle missions. Many of these lessons learned from the Space Shuttle and Shuttle-Mir Programs were applied to the International Space Station providing a safer and more productive environment for astronauts and cosmonauts.

\section{Identification of Microbiological Hazards and Risks}

Microorganisms will accompany all space vehicles and space habitats occupied by humans. The closed environments of spacecraft increase the importance of microorganisms in our efforts to keep astronauts healthy, safe, and productive. The absence of a one-gravity vector (i.e., weightlessness) in space prevents the removal of bacteria, fungi, and particulates from the air by settling as occurs on Earth. While the majority of microorganisms are not harmful and many are beneficial to human health and Earth's ecology, some microorganisms are associated with adverse effects such as infections, degradation of spacecraft materials, and many others (Figure 1). Biodegradation of critical materials can result in system failures that may endanger crews. Evidence gained during the SSP suggests that infectious diseases and allergic responses may increase on long exploration missions due to sustained immune deficiencies (11-15) and increased virulence of some microorganism (7-10).

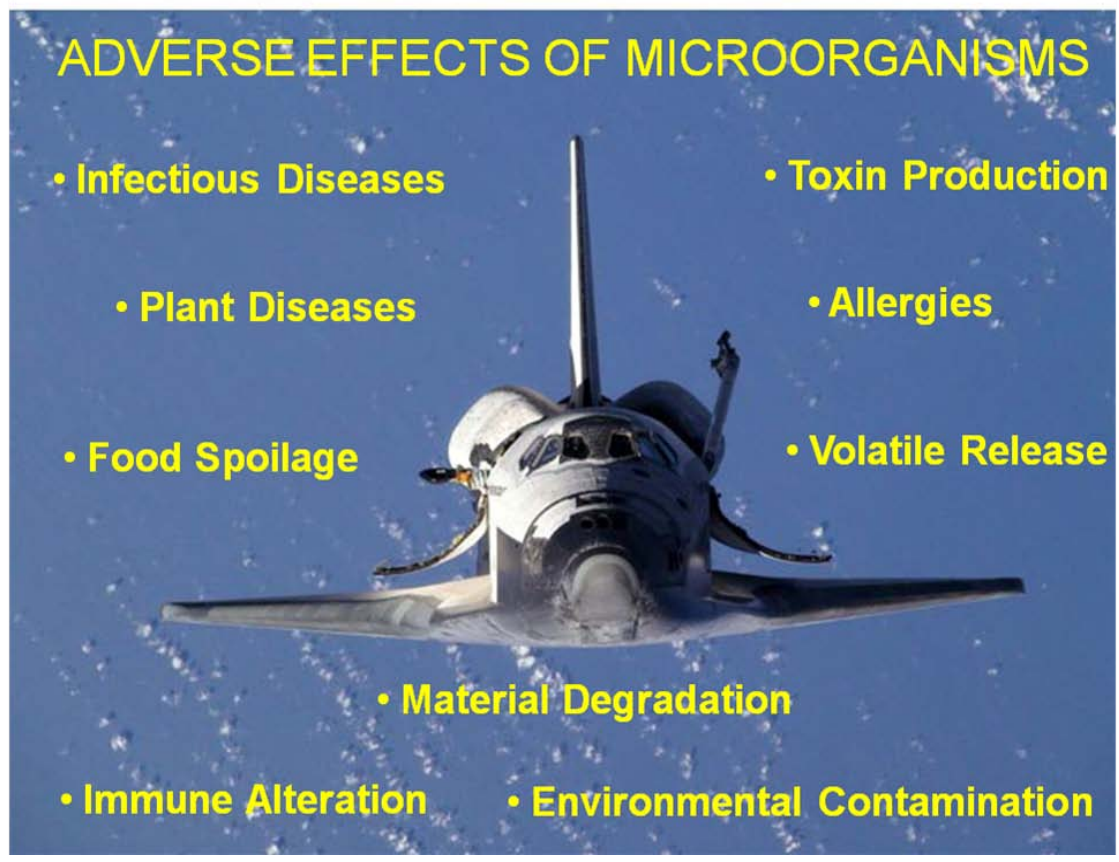

Figure 1. Adverse Effects of Microorganisms in the Space Environment. 


\section{Strategy to Mitigate Microbiological Risks}

The major microbiological risk factors for astronauts include: food, drinking water, air, surfaces, payloads, animals, crewmembers, and personnel in close contact with the astronauts. In our efforts to eliminate or mitigate the negative effects of microorganisms in spacecraft, NASA implemented comprehensive microbial analyses of the major risk factors. This effort includes sample collection and analyses of food, water, air, surfaces, and crew. The accompanying requirements and acceptability limits were developed to combat the major risks. A robust monitoring program was implemented to validate that the risks were within acceptable limits.

\section{A. Acceptability Limits and Sampling Schedules}

Requirements for bacteria and fungi in the spacecraft air, surfaces, and drinking water are shown in Tables 1 and 2 and documented in the Space Shuttle Medical Operations Requirements Document (20-22). These requirements were established through scientific and medical expert panels utilizing professional experience and federal standards where available. As new data emerged, sampling schedules and acceptability limits were altered. The air and surface standards applied to preflight measurements and did not apply to in-flight values.

\begin{tabular}{|l|l|l|}
\hline & \multicolumn{1}{|c|}{ Maximum for Bacteria } & \multicolumn{1}{c|}{ Maximum for Fungi } \\
\hline Air & $300 \mathrm{CFU} / \mathrm{m}^{3}$ & $50 \mathrm{CFU} / \mathrm{m}^{3}$ \\
\hline Internal Surfaces & $500 \mathrm{CFU} / 100 \mathrm{~cm}^{2}$ & $10 \mathrm{CFU} / 100 \mathrm{~cm}^{2}$ \\
\hline
\end{tabular}

Table 1. Preflight Microbial Specifications for Air and Surfaces.

\begin{tabular}{|l|c|c|c|}
\hline & $\begin{array}{c}\text { Maximum for } \\
\text { Bacteria }\end{array}$ & $\begin{array}{c}\text { Maximum } \\
\text { Coliform Bacteria }\end{array}$ & $\begin{array}{c}\text { Maximum for } \\
\text { Protozoa }\end{array}$ \\
\hline $\begin{array}{l}\text { Potable water, technical } \\
\text { water, CWCs }\end{array}$ & $50 \mathrm{CFU} / \mathrm{mL}$ & Non-detectable & $\begin{array}{l}\text { Water must be filtered } \\
\text { during preparation } \\
\text { using a 1 micron filter }\end{array}$ \\
\hline
\end{tabular}

\section{Table 2. Microbial Specifications for Shuttle Potable Water}

Early in the SSP, environmental samples were collected prior to flight and again post flight from the interior surfaces and air of the crew compartment as part of the Microbiology Operations Plan (1) implemented to ensure the health, safety, and performance of the astronauts. Air and surfaces samples were collected after the shuttle arrived at the launch pad (nominally at about 15-25 days before launch) and again at approximately 2 days before launch. The same surface sites were sampled immediately upon landing (early in SSP). Post flight sampling of air and surfaces was discontinued later in the program along with sampling two days prior to launch.

To reduce the risk of zoonotic disease, microbiologists at NASA's Johnson Space Center and veterinarians established the microbiology requirements for animals used for experimentation aboard the Space Shuttle. Investigational animals included primates, rodents, and amphibians. These efforts were coordinated through the NASA Committee for the Protection of Human Subjects and with the NASA Veterinarian.

\section{B. Air Monitoring}

Air samples were collected from the Middeck, Flight deck, and the Spacelab by using one of several small, portable, battery operated air samplers. Air samplers were selected following comparative studies (23, 24,). Table 1 shows the acceptability limits for bacteria and fungi in crew compartment air prior to launch. No acceptability limits were defined for the in-flight phase. Air samples were collected at 15-25 days prior to launch and again at two days before launch. 
Air samples were collected during the flight phase of 14 Space Shuttle missions over a 10 year period. The mission duration ranged from five days to 16 days and different Space Shuttles were included in the studies. The air samples collected during the various missions were taken from the Flight Deck, the Middeck, and the Spacelab when present. Generally, the airborne bacteria tended to increase during the mission in both the orbiter and the Spacelab. At times the bacterial levels exceeded 1000 colony forming units (CFU) per cubic meter $\left(\mathrm{M}^{3}\right)$ of air. More commonly, the levels of bacteria in both the orbiter and the Spacelab were low. More important than the levels of microorganisms are the types of bacteria present in the air. The bacteria recovered from the in-flight air samples from 14 shuttle missions were most frequently included: Staphylococcus spp., Micrococcus spp., Bacillus spp., and Enterobacter spp. These bacterial genera were typically associated with humans and the environment and were present in at least $85 \%$ of the samples and tended to increase with mission duration. The most commonly recovered fungal genera recovered from the air samples from 14 shuttle missions included: Aspergillus spp., Penicillium spp., and hyphomycetes were the predominating fungal species found. These common environmental genera were recovered from $60-80 \%$ of the air samples (25). Unlike the continuous increase of bacteria in the air, fungi tended to decrease in the air as the missions progressed. This decrease was likely due to low humidity, little free water, and no major source of fungi.

Particulates were also measured in the crew compartment and showed an unusual size distribution over time in the crew compartment (26). As expected larger particulates that settle quickly on Earth remained suspended much longer in the microgravity environment of the Space Shuttle. Debris of assorted material was collected on the 70-300 micron stainless mesh filters (Figure 2). A cabin air cleaner was installed during the Extended Duration Orbiter Medical Project to remove particulates and microorganisms. This resulted in reductions in airborne particulates and microorganisms and fewer crew complaints. This cabin air cleaner was later used on all Space Shuttle missions.

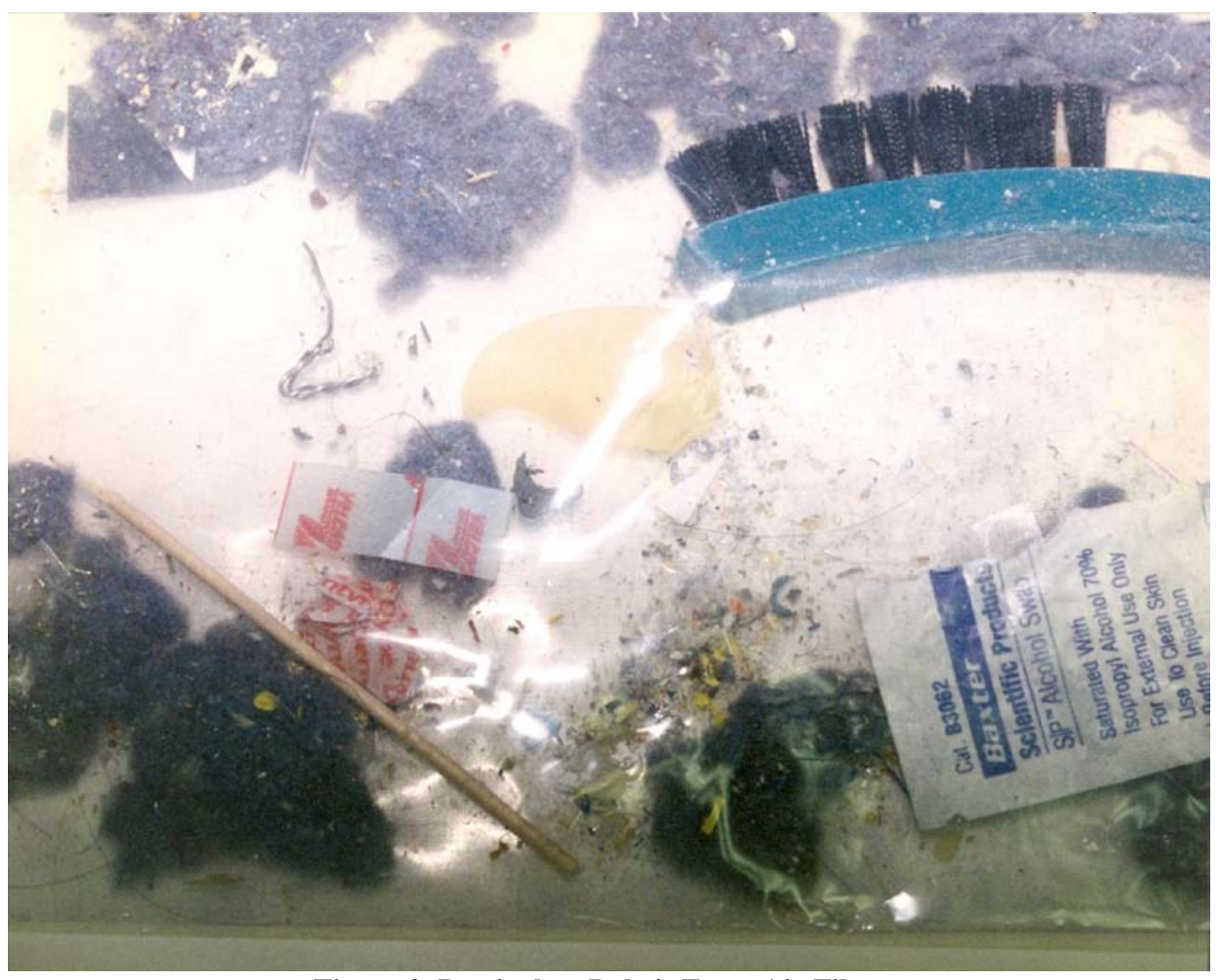

Figure 2. Particulate Debris From Air Filters. 


\section{Surface Monitoring}

Interior surfaces of the Space Shuttle were sampled to coincide with air sampling from the Middeck, Flight deck, and Spacelab (when present). Interior surfaces of the Space Shuttle and the Spacelab were sampled before launch and once after landing to observe any buildup of microorganisms on surfaces. Ten surface sites were sampled during 13 Space Shuttle missions and the bacterial species recovered included: Staphylococcus spp., Micrococcus spp., and Bacillus spp. (100\% of samples) while Corynebacterium spp., and Enterobacter spp. were recovered from 60 to $80 \%$ of the surface samples. A study of 70 Space Shuttle missions found that nearly half of the surface sites showed a 10-fold or greater buildup of bacteria during a mission (25).

\section{Food Analysis}

Food for consumption by flight crews is analyzed for total bacteria and selected pathogens. Air and surface monitoring of the food preparation area reduces risks of additional microbial contamination. Representative samples of foods prepared for crew consumption are rigorously analyzed to ensure safe products for the crewmembers. Foods are analyzed for total aerobic bacteria and total yeast and mold. Generally, foods cannot exceed 20,000 CFU of bacteria per gm. Mold and yeast cannot exceed $1000 \mathrm{CFU}$ of yeast or mold per gm. Foods are also tested for the presence of specific pathogens including Staphylococcus aureus and Salmonellae (27). All foods destined for crew consumption met NASA acceptability limits.

\section{E. Water Analysis}

Drinking water was provided by fuel cells during the mission. Prior to flight the water tanks were filled by ground-supplied municipal water. The ground-supplied water was filtered through a 0.1 micron filter to remove microbial contaminants and iodine was added to provide 2-3 ppm residual iodine. Shuttle water was analyzed for total bacteria and coliforms. Fungi were not recovered and were not routinely included in analyses after initial missions. Approximately half of the ground-supplied water was removed just prior to launch to make room for fuel cell provided water on assent.

The drinking water onboard the orbiter was monitored several times prior to launch and again upon landing. The water during flight was provided by the fuel cells and 2-3 ppm of iodine was added by an iodinated resin as a residual disinfectant. The acceptability limits for total bacteria ranged from 1 CFU/100 ML (early in the SSP) to $50 \mathrm{CFU} / \mathrm{ML}$ during the latter years of the SSP (Table 2). The water was analyzed for coliforms according to the requirements of the Environmental Protection Agency. Whereas the total bacteria exceeded the acceptability limit occasionally, no coliforms were ever detected in Space Shuttle water $(28,29)$. The number of bacteria (heterotrophic plate count) has little bearing on human health, but is a highly valuable measurement of overall system operation. Again the types of bacteria are more important to crew health than the total number of bacteria. The bacteria recovered were typical waterborne, gram-negative bacteria, and Burkholderia cepacia was the most common genus recovered. The bacterial levels in Space Shuttle water were far below levels found in most municipal water systems.

\section{F. Payload Reviews}

The NASA Biosafety Review Board (BRB) reviews all payloads as part of the overall safety evaluation conducted by the Payload Safety Review Panel (30). Biohazardous materials are identified and the level of containment needed to safeguard the crew and the integrity of the spacecraft is assigned. The BRB uses the NIH/CDC and the World Health Organization in characterizing the levels of hazard. The BRB identifies the biohazardous materials and assigns a biosafety level (e.g., Biosafety Level 1). Whereas numerous Biosafety Level 2 microorganisms have flown aboard the Space Shuttle, no Biosafety Level 3 agents were flown because of insufficient containment capabilities. Biosafety Level 2 agents require 2-3 levels of containment depending upon circumstances. The BRB also reviews in-flight operations and ground laboratories conducting operations and research involving biohazardous materials at the Johnson Space Center.

\section{G. Crew Health}

During early phases of the SSP, the microbiological evaluation of flight crews included preflight and postflight collection and analyses of feces, urine, nose, throat, and some selected skin sites (25). Antibiotic susceptibility testing of medical important species was conducted to provide data to Flight Surgeons in case of infectious illness among crewmembers. This rigorous evaluation was later reduced to preflight and post flight screening of crewmembers for methicillin resistant Staphylococcus aureus (MRSA) by using nasal swabs. Of course, if crewmembers exhibited symptoms, a full range of diagnostic tests could be implemented by the College of 
American Pathologists accredited laboratory. The crewmembers are exceptionally healthy and well-conditioned, and the microorganisms recovered by pre- and post flight examinations showed microbial profiles consistent with healthy individuals $(5,25)$. Detailed investigations showed that while bacteria and fungi migrated among the crew, permanent colonization was rare (31-33).

\section{A. Preflight Space Shuttle Air}

\section{Anomalies}

Preflight sampling of the Space Shuttle on the launch pad consists of using a small portable, battery operated air sample to collect air from both the middeck and flight deck of the orbiter. Bacterial levels were typically within the acceptability limits (Table 1). However, early in the SSP, preflight fungal levels were exceptionally high in the Shuttle crew compartment even exceeding outside air levels. Microbiologists suspected a large flex-hose used to provide outside air into the crew compartment. The hose allowed excessive growth of fungi within the hose. A High Efficiency Particulate Air (HEPA) filter was installed to remove the contaminants in the air before entering the cabin. Subsequently, the bacterial and fungal levels remained exceptionally low in the crew compartment. HEPA filtration of the outside air supply provided breathing air with lower fungi and bacteria than most homes and offices.

\section{B. Noxious Odor}

On the STS-55 mission, a container not designed for human waste was used as a contingency container for crew urine. Common bacteria found in urine decomposed organic compounds in the urine producing noxious byproducts including three dimethysulfides (34). This incident shows that bacterial and chemical contaminations are not independent problems in closed environments. Microorganisms contribute many volatile compounds that may cause crew discomfort to the spacecraft environment.

\section{In-Flight Air}

Air quality with respect to particulates and microorganisms was generally good. However, crewmembers occasionally experienced eye irritation and complained of visible particulates in the cabin air. An investigation demonstrated that particulates of all sizes have a much longer residence time in the cabin air because of absence of gravity vector (24). Considerable debris was recovered from air filters for examination (Figure 2). As missions became longer, a portable cabin air filtration unit with a fine filter was deployed to the space shuttle middeck and resulted in marked improvement of the air. Crew complaints were reduced. This anomaly resulted in the JSC Microbiology Laboratory introducing a requirement for HEPA filters in the environmental life support system of the International Space Station.

\section{Lack of Containment}

The Spacelab-3 mission included squirrel monkeys housed in the Research Animal Holding Facility (RAHF) in the Spacelab. Debris consisting of mostly food bars and perhaps small amounts of animal feces escaped into the Spacelab environment and eventually into the crew cabin of the Orbiter. This resulted in the suspension of such investigations until the RAHF underwent an expensive and time consuming redesign.

\section{E. Crew Illness}

Only one Space Shuttle mission, STS-38, was delayed because of symptoms of a possible infectious disease. Various symptoms occurred in more than one crewmember and the etiology was not determined. However, an investigation by microbiologists resulted in changes in food storage procedures in the JSC Crew Quarters.

Diagnosis of on-orbit illnesses was difficult due to lack of physician-patient direct contact and lack of onboard diagnostic capabilities. Illnesses of microbiological origin were mild in most cases. Skin infections were the most common. An occasional urinary tract infection and upper respiratory infections have also occurred. One upper respiratory infection was caused by a preflight contracted parainfluenza virus as determined by viral titers. Some discomfort was experienced by several crewmembers during the flight, but all mission objectives were achieved. Most respiratory viruses with incubation periods of 3-5 days are prevented by the preflight Health Stabilization Program that limits crew contact with high risk groups. 


\section{Research}

Many studies of humans, animals, plants, and microorganisms were conducted on the Space Shuttle/Spacelab and greatly advanced our understanding of human and microbial physiology. GGreat strides in understanding the all important human-microbe interactions were made during the SSP.

\section{A. Latent Virus Reactivation}

Many studies of human and animal physiology were conducted on the Space Shuttle/Spacelab and greatly advanced our understanding of human physiology. Table 3 summarizes the findings of human immunity during the Space Shuttle era (11-15). Establishing the medical risk associated with the many changes observed in human immunity proved difficult. Technical limitations prevented most in-flight measurements of immune function. In the search for medically-related immune changes led to a long running series of investigations of reactivating latent herpes viruses in astronauts during all flight phases. Factors associated with spaceflight resulted in substantial increases in reactivation Epstein-Barr virus (16), cytomegalovirus $(17,18)$, and varicella zoster virus (VZV) (19). These increases are consistent with reductions in cell-mediated immunity. Finding live, infectious VZV in saliva of asymptomatic astronauts was one of several novel findings. After years of study aboard the Space Shuttle, the reactivation of viruses is now an accepted as a much needed biomarker of decreased cellular (T-cell) immunity. These studies resulted in new basic discoveries that were applied to patients on earth. Expansion of these basic findings in astronauts has benefited patients in the general population (35). VZV typically causes chickenpox in children and subsequently shingles in adults. One million new cases of painful shingles occur in the U.S. each year and up to 200,000 new cases of post herpetic neuralgia, a common complication that is characterized by extreme pain lasting for months or years. Blindness can also result from VZV infections, and up to 20 percent of shingles cases result in serious viral infections of the eye. Many of the symptoms of this painful disease can be prevented or mitigated by rapid diagnosis and prompt antiviral treatment. Shingles results from the reactivation of VZV that remains in the body following chickenpox. When VZV reactivates, it appears in the saliva prior to the appearance of the characteristic painful shingles rash. NASA developed a non-invasive, rapid, and very sensitive molecular test using saliva that detects the virus and allows for rapid antiviral therapy. This cutting edge technology utilizes saliva for VZV DNA identification that can provide unequivocal results within two hours from sample collection. This prevents misdiagnosis and delayed treatment. The benefits of this technology have been demonstrated in shingles patients. A second test based on antibody detection of VZV surface antigens is designed for use in physician offices, remote locations, or home use (Patent Pending).

\section{CHANGES IN HUMAN IMMUNITY}

- Altered circulating leukocyte distribution.

- Altered cytokine production patterns (secreted, intracellular, Th1/Th2).

- Decreased NK cell function.

- Decreased granulocyte function.

- Decreased T cell function.

- Altered immunoglobulin levels.

- Increased latent viral reactivation.

- $\quad$ Altered virus-specific immunity.

- Expression of EBV IE/late genes.

- Altered neuroendocrine responses.

Table 3. Changes in Human Immunity.

\section{B. Increased Virulence in Microorganisms}

Historically, the study of microbial responses to extreme environments, such as severe shifts in $\mathrm{pH}$, osmotic concentration, or temperature, has provided tremendous insight into our understanding of how pathogens adapt and respond during the infection process in vivo. For pathogens, many of these conditions reflect the environment that they encounter during the normal infection process. Scientists from The BioDesign Institute at Arizona State University hypothesized that the low fluid shear environment of spaceflight imparts physical conditions similar to areas encountered by pathogens during infection of the human host and that this environment may induce changes in the organism's virulence characteristics. 
To gain insight into this hypothesis, Nickerson et al. $(7,8)$ performed experiments aboard STS-115 and STS-123, operationally designated MICROBE and MDRV, in which the virulence, morphological characteristic, and molecular genetic responses of Salmonella enteric serovar Typhimurium (S. Typhimurium) during flight were compared to identically grown cultures on the ground. Microscopic analysis of the spaceflight grown $S$. Typhimurium from STS-115 indicated the presence of an extracellular matrix not seen in the ground grown controls, suggesting the potential of enhanced biofilm formation by the spaceflight cultures. In addition, S. Typhimurium cultured aboard STS-115 displayed a 2.7 times greater virulence in a murine model of infection compared to ground control (7). This experiment was reproduced aboard STS-123 in which spaceflight grown cultures displayed 6.9 fold greater virulence (8). Interestingly, this change in virulence was found to be manipulated by the growth media content, as the enhance disease causing potential was mitigated with the addition of high ionic salts to the media. Further testing using ground-based analogues suggested that the key salt that mitigated this effect was inorganic phosphate.

One of the most important findings by Nickerson et al. (7) was the identification of molecular genetic changes in $S$. Typhimurium as a result of spaceflight. In the experiment aboard STS-115, the $S$. Typhimurium cultured in the spaceflight environment differentially expressed 167 genes compared to ground controls. Of special note, the conserved RNA-binding protein Hfq was identified as a likely global regulator involved in the response to this environment. The association of Hfq with changes in gene expression was again seen with cultures of Pseudomonas aeruginosa also cultured during the MICROBE experiment (6). Taken together, these findings suggest the observed changes in bacteria are regulated by a concerted molecular mechanism, thus providing insight into infectious disease risk to astronauts and possibly the general public on Earth.

The finding of increased virulence in a wide array of microorganisms as a result of the spaceflight environment is perhaps the most important microbiological discovery of the Space Shuttle era.

\section{Conclusions}

Many microbiological lessons were learned from the Space Shuttle era. The major sources of microbiological risks to the crew are associated with the food, water, air, surfaces, payloads, animals, and crewmembers. Adverse effects of microorganisms are many and can jeopardize crew health and safety and mission objectives.

Prevention of microbiological problems is preferred over mitigation of problems in-flight, and preventive steps must begin very early in design phase (Table 4). To minimize problems of microbiological origin, mitigating steps must begin in the design phase of any new spacecraft or space habitat. Spacecraft design must include requirements to control free water whether through humidity or condensate. If water is available, microbes will grow because sufficient nutrients are usually available. Spacecraft materials must not promote or support microbial growth. Air filtration can dramatically reduce airborne bacteria, fungi, and particulates from spacecraft breathing air. Waterborne bacteria can be reduced to acceptable levels by heat during processing along with a residual biocide. Filtration at point of use can ensure safety. Capability to recover contaminated system should be included.

The Space Shuttle provided greatly improved access to space and ushered in an era of human and space studies. A much better understanding of the effects of spaceflight on humans was the product of these studies. From a microbiological perspective: (1) Human host and microbe interactions were found to be altered. These include increased microbial virulence and increased reactivation of viruses. (2) Human immunity was found to be affected, generally reduced in shuttle astronauts. Specifically, T-cell function was reduced along with elements of innate immunity. (3) Selected microorganisms were found to become more virulent during spaceflight. These studies are currently being continued on the ISS. 


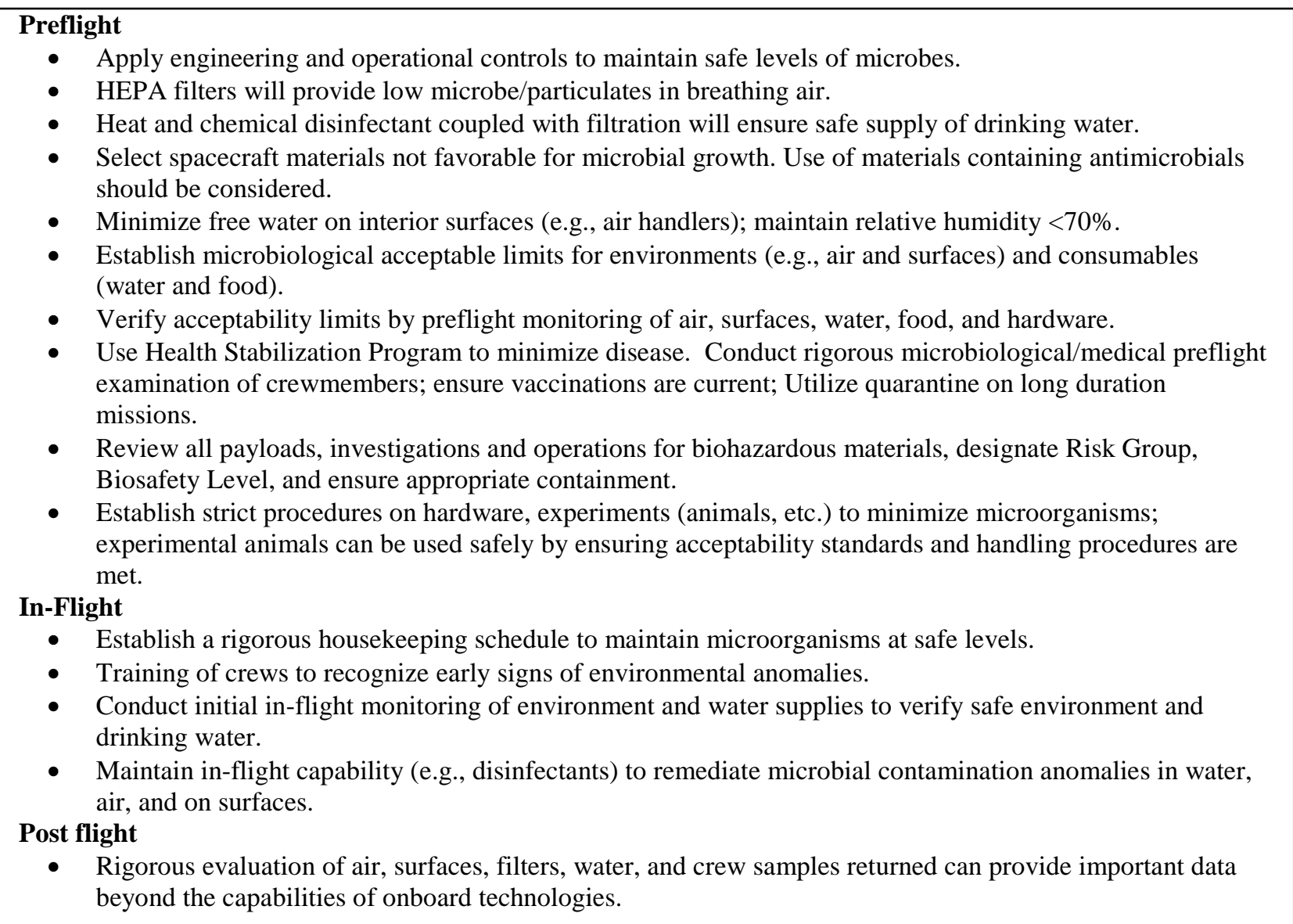

Table 4. Operational Lessons Learned From the Space Shuttle Era

\section{References}

1. Microbiology Operations Plan for Spaceflight. JSC-16888 Rev. C. NASA Internal Document

2. $\quad$ Burge, S., Hedge, A., and Wilson, S. 1987. Sick Building Syndrome: A Study of 4373 Office Workers. Ann. Occup. Hyg. 31 (4A): 493-504.

3. Ferguson, J. K., GR Taylor, and Mieszkuc. B. J. 1975. Microbiological Investigations. In Biomedical Results of Apollo (R.S. Johnston and L.F. Dietlein, C.A. Barry, eds). Scientific and Technical Information Office, NASA. Pp 83-103.

4. Taylor, G. R., Graves, R. C., Brockett, R. M., Ferguson, J. K., and Mieszkuc, B. J., "Skylab Environmental and Crew Microbiology Studies,” Biomedical Results from Skylab, edited by Richard S. Johnston and Lawrence F. Dietlein, NASA Johnson Space Center, Scientific and Technical Information Office, National Aeronautics and Space Administration, Washington, D.C., 1997, Chapter 8, pp. 53-63.

5. $\quad$ Pierson, D.L. 1993. Microbiology (chapter 8). In: Space Physiology and Medicine, 3rd edition. Eds. A.E. Nicogossian, C.L. Huntoon, and S.L. Pool. Lea and Febiger, Philadelphia, pp. 157-166.

6. Pierson, D.L. 2001. Microbial contamination of spacecraft. Gravitational and Space Biology Bulletin 14(2), 1-6. 
7. Crabbé, A., Schurr, M.J., Monsieurs, P., Morici, L., Schurr, J., Wilson, J.W., Ott, C.M., Tsaprailis, G., Stefanyshyn-Piper, H., Nickerson, C.A. (2011) Response of Pseudomonas aeruginosa PAO1 to spaceflight conditions involves Hfq regulation and reveals a role for oxygen. Appl Environ Microbiol 77(4):12211230.

8. Wilson, J.W., Ott, C.M., Honer zu Bentrup, K., Ramamurthy, R., Quick, L., Porwollik, S. et al. (2007) Space flight alters bacterial gene expression and virulence and reveals a role for global regulator Hfq. Proc Natl Acad Sci U S A 104: 16299-16304.

9. Wilson, J.W., Ott, C.M., Quick, L., Davis, R., zu Bentrup, K.H., Crabbé, A. et al. (2008) Media ion composition controls regulatory and virulence response of Salmonella in spaceflight. PLoS ONE 3: e3923.

10. Ott, CM, A Crabbé, JW Wilson, J Barrila, SL Castro, CA Nickerson. In Press. Microbial Stress: Spaceflight-induced alterations in microbial virulence and infectious disease risks for the crew. Stress Challenges and Immunity in Space (A Chouker, ed.) Springer, Heidelberg, Germany.

11. Mehta, S. K., Kaur, I. Grimm, E. A., Smid, C., Feeback, D. L., and Pierson, D. L. 2001. Decreased NonMHC-Restricted $\left(\mathrm{CD}_{56}{ }^{+}\right.$) killer-cell cytotoxicity after spaceflight. J. Applied Physiology 91: 1814-1818.

12. Kaur, Indreshpal, Simons, Elizabeth R., Castro, Victoria, and Pierson, Duane L. 2004. Changes in neutrophil functions in astronauts. Brain, Behavior, and Immunity 18: 443-450.

13. Ott, C. M., Bruce, R. J., and Pierson, D. L. 2004. Microbial Diversity Aboard Spacecraft: Evaluation of the Mir Space Station. Microbial Ecol. 47: 133-136.

14. Kaur, I., Simons, E.R., Castro, V.A., Ott, C.M., and Pierson, D.L. 2005. Changes in Monocyte Functions of Astronauts. Brain Behavior and Immunology 19: 6:547-554.

15. Gueguinou N, Huin-Schohn C, Bascove M, Bueb JL, Tschirhart E, Legrand-Frossi C, et al. Could spaceflight-associated immune system weakening preclude the expansion of human presence beyond Earth's orbit? J Leukoc Biol 2009; 86(5):1027-38.

16. Pierson, D., Stowe R., Phillips, T., Lugg, D., and Mehta, S. 2005. Epstein-Barr Virus Shedding by Astronauts during Space Flight. Brain Behavior and Immunity 19:3: 235-242.

17. Pierson, Duane L., Mehta, Satish K., and Stowe, Raymond P. Reactivation of Latent Herpes Viruses in Astronauts. Psychoneuroimmunology 4E, Vol II, 851-868, 2007.

18. Mehta, S. K., Stowe, R. P., Fieveson, A. H., Tyring, S. K., and Pierson, D. L. 2000. Reactivation and shedding of cytomegalovirus in astronauts during space flight. J. Inf. Dis. 182: 1761-1764.

19. Mehta, Satish K., Cohrs, Randall J., Forghani, Bagher, Zerbe, Gary, Gilden, Donald H., and Pierson, Duane L. 2004. Stress-induced subclinical reactivation of varicella zoster virus in astronauts. J. Med. Vir. 72:1: 174-179

20. International Space Station Medical Operations Requirements Document (ISS MORD), SSP 50260, NASA Internal Document.

21. Medical Operations Requirements Document for Space Shuttle (Shuttle MORD), JSC 13956, NASA Internal Document.

22. Space Shuttle Specification, Fluid Procurement and Use Control, SE-E-0073, NASA Internal Document.

23. Mehta, S.K., Mishra, S.K., and Pierson, D.L. 1996. Evaluation of 3 portable samplers for monitoring airborne fungi (Note). Applied and Environmental Microbiology 62(5): 1835-1838. 
24. Mehta, S.K., Bell-Robinson, D.M., Groves, T.O., Stetzenbach, L.D., and Pierson D.L. 2000. Evaluation of Portable Air Samplers for Monitoring Airborne Culturable Bacteria. Journal of American Industrial Hygiene Association 61: 850-854.

25. Pierson, D., James, J., Russo, D., Limero, T., Beck, S., and Groves, T. 1989-1995. Environmental Health. In: Extended Duration Orbiter Medical Project. Final Report. NASA/SP 1999-534, Section 4, pp. 4-1 - 4-11.

26. Lui, B., Rubow, K., McMurry, P., Kotz, T., and Russo, D. 1991. Airborne Particulate and Spacecraft Internal Environments. SAE Technical Paper Series no. 911476, Society of Automotive Engineers, Warrendale, PA.

27. Internal NASA Standard: SD-T-0251, Microbiological Specification and Testing procedure for Foods Which Are Not Commercially Sterile

28. Koenig, D. W., and Pierson, D. L. 1997. Microbiology of the space shuttle water system. Water Sci. Tech 35:59-64.

29. Koenig, D.W., Bell-Robinson, D.M., Johnson, S.M., Mishra, S.K., Sauer, R.L., and Pierson, D.L. 1995. Microbiological analysis of water in space. SAE Technical Paper Series no. 951683, Society of Automotive Engineers, Warrendale, PA.

30. Biosafety Review Board Operations and Requirements Document. JSC 63828. NASA Internal Document.

31. Pierson, D.L., Chidambarum, M., Heath, J.D., Mallary, L., Mishra, S.K., Sharma, B., and Weinstock, G.M. 1996. Epidemiology of Staphylococcus aureus in the Space Shuttle. FEMS Immunology \& Medical Microbiology 16: 273-281.

32. Pierson, DL, SK Mehta, BB Magee, SK Mishra. 1995. Person-to-person transfer of Candida albicans in the spacecraft environment. J Med Vet Mycol 33:145-150.

33. Pierson, D.L., Bassinger, V.J., Molina, T.C., Gunter, E.G., Groves, T.O., Cioletti, L.J., and Mishra, S.K. 1993. Preflight and post flight microbiological results from Space Shuttle crews. SAE Technical Paper Series no. 932139, Society of Automotive Engineers, Warrendale, PA.

34. James, J. T., Limero, T. F., Leano, H. J., Boyd, J. F., and Covington, P. A. 1994. Volatile Organic Contaminants Found in the Habitable Environment of the Space Shuttle: STS-26 to STS-55. Aviation, Space, and Environmental Medicine 851-857.

35. Mehta, Satish, K., Stephen K. Tyring, Gilden, Donald H, Cohrs, Randall J., Leal, Melanie J., Castro, Victoria A., Feiveson, Alan H., Ott, C. Mark, and Pierson, Duane L. 2008. Varicella Zoster Virus in Saliva of Patients with Herpes Zoster. Journal of Infectious Disease 197:65 